\title{
SUSTAINABLE FUELS OBTAINED FROM THE PYROLYSIS PROCESS OF SEWAGE SLUDGE
}

\author{
Anca Maria Zaharioiu ${ }^{1,2^{*}}$, Felicia Bucura ${ }^{1}$, Florian Marin ${ }^{1}$, Roxana Elena Ionete ${ }^{1}$, \\ Simona Oancea ${ }^{2}$, Marius Constantinescu ${ }^{1}$ \\ ${ }^{1}$ National Research and Development Institute for Cryogenic and Isotopic Technologies - ICSI Rm. Valcea, \\ 4 Uzinei Str., 240050 RamnicuValcea, Romania \\ ${ }^{2}$ Faculty of Agricultural Sciences, Food Industry and Environmental Protection, "Lucian Blaga" University of Sibiu, \\ 7-9 I. Ratiu Str., 550012 Sibiu, Romania
}

\begin{abstract}
Combustion of fossil fuels, greenhouse gas emissions, large amounts of sewage sludge, lead to environmental pollution and global warming. For this reason we must think of feasible solutions to disposal the sewage sludge by capitalization it and energy recovery. One of the most interesting technologies for disposal the sewage sludge is the pyrolysis process. After the pyrolysis process of sewage sludge are obtained three types of products: bio-oil, syngas and biochar. Bio-oil can be used as an alternative fuel for fossil fuels after refining. Bio-char can be used as an adsorbent after an activation process for the capture and storage $\mathrm{CO}_{2}$. Pyrolysis is considered an environmentally friendly process because it reduces the emission of greenhouse gases, while heavy metals are concentrated in the final residue. In this paper are presented the advantages of sewage sludge pyrolysis.
\end{abstract}

Keywords: Bio-char, bio-oil, pyrolysis, sewage sludge, syngas

\section{INTRODUCTION}

Greenhouse gas emissions are considered the main factor of climate changes, generating a negative impact on the environment. Carbon dioxide is the gas with the largest contribution to global warming, due to its extensive production through burning fossil fuels, activities of the industrial sector and electricity generation (Hong et al., 2016; Chiang and Juang, 2017). Due to anthropogenic activities, the $\mathrm{CO}_{2}$ concentration increased considerably from $280 \mathrm{ppm}$ to $400 \mathrm{ppm}$ during the last 10 years (Lee and Park, 2015; Rashidi and Yusup, 2016; Jang et al., 2018). It has been estimated that the atmospheric concentration of $\mathrm{CO}_{2}$ will reach $570 \mathrm{ppm}$ in 2100 , which will generate extreme climate changes, such as: melting glaciers and ice caps which causes rising planetary ocean levels, heavy rainfall, extreme droughts (Lee and Park, 2015). All these issues are of great concern, and research is focused on developing $\mathrm{CO}_{2}$ capture and storage technologies to prevent climate change (Deng et al., 2014; Hong et al., 2016).

Sewage sludge is a solid waste resulting from the treatment of wastewater from treatment plants and is in increasing quantities. The production of sewage sludge in Europe is of 10.13 million tons, compared to China, where there are more than 25 million tons produced annually (Milieu, 2010; $\mathrm{Lu}$ et al., 2013). At present, the disposal methods of sewage sludge are as following: incineration, use 
in agriculture and landfill. Due to potential contaminants of sewage sludge, such as heavy metals, organic compounds, pathogens, it can no longer be used in agriculture, according to the European Directive 86/277/EEC (Fonts et al., 2012; Cantinho et all., 2016). Another disposal method of sewage sludge is soil storage, but it becomes of risk for plants, animals and human health due to the high content of heavy metals, viruses and pathogenic bacteria (Singh and Agrawal, 2008). Disposal of sewage sludge by incineration has the advantage of reducing the amount of sludge by up to $70 \%$, but it may release pathogens, toxic organic compounds, dioxins and furans, nitrogen oxides, sulfur oxides, heavy metals, all of which are harmful to the environment and human health (Khiari et al., 2004; Hwang et al., 2007; Fytili and Zabaniotou, 2008).

The use of renewable energy and the development of carbon capture and storage technologies are important because they reduce $\mathrm{CO}_{2}$ in the atmosphere produced by power and industrial plants. $\mathrm{CO}_{2}$ captured from industrial sources can be used in various ways, such as transportation and injection into geological formations such as saline aquifers, gas fields, coal mines (Jacobson, 2009; Liu and Wilcox, 2011).

The production of biofuels from biomass or wastes is performed through the processes of pyrolysis, gasification, incineration and roasting. Among them, the most appropriate and used is the pyrolysis process due to the high calorific value and the heat it generates (Capareda, 2013; Gao et al., 2014). The use of sewage sludge in the pyrolysis process produces biofuels such as: bio-oil, syngas and biochar (Pokoma, 2009). The pyrolytic products obtained can be used in the composition of aromatic agents, fertilizers or resins (Iguanzo et al., 2002; Tian et al., 2011). The pyrolysis process of sewage sludge considerably reduces environmental pollution (Manara and Zabaniotou, 2012). The pyrolysis parameters can be adjusted to improve the production of some of the products: biochar, bio-oil or syngas (Maguyon and Capareda, 2013). To improve the yield of bio-oil, fast pyrolysis is used, at moderate temperatures of $500{ }^{\circ} \mathrm{C}$, high heating rate and rapid vapor condensation (Fonts et al., 2012; Yin et al., 2012).

The pyrolysis process of the sewage sludge consists of the decomposition of organic substances, under nitrogen atmosphere and in the absence of oxygen, at a certain temperature, with the production of syngas, bio-oil and biochar (Liu et al., 2011; Liu et al., 2017; Zhang et al., 2017). Pyrolysis of sewage sludge has a lightning trajectory and rapid development because of its benefits: reducing the amount of sewage sludge, application of the final products as a sustainable energy source (Leng et al., 2016; Peng et al., 2016; Yu et al., 2016). Prior to the pyrolysis process, the sewage sludge must be dried in order to remove the high content of water, such as to conduct an efficient thermal process (Kan et al., 2016).

\section{SEWAGE SLUDGE CHARACTERISTICS}

Wastewater that reaches treatment plants is treated by several methods: preliminary, primary and secondary treatments. The first stage, the preliminary treatment, consists in sifting the raw sludge to remove coarse residues such as rock, gravel, textiles, sand, while the suspended organic matter remains in the water. The primary treatment remove the solids, oils, greases and other floating materials and a proportion of the organic load. Properly performed, the primary treatment processes should remove from $50 \%$ to $70 \%$ of the solid suspensions and from $25 \%$ to $40 \%$ of the organic load. The sludge resulting from the primary treatment has a water content of $93-99 \%$ and a high content of suspended organic matter. Secondary treatment is actually a biological process, purification, a biotreatment with biological agents performed in order to stabilize organic matter 


\section{Current Trends in Natural Sciences}

Vol. 10, Issue 19, pp. 16-24, 2021

https://doi.org/10.47068/ctns.2021.v10i19.002

(Pathak et al., 2009; Tinto et al., 2016). The concentration of solids in the secondary sludge is in proportion of $0.8-1.2 \%$ (Tezel et al., 2011).

The sewage sludge is a complex waste, being composed of microorganisms, fats, proteins, peptides, dioxins, furans, polycyclic aromatic hydrocarbons and other compounds (Dress, 2002). Table 1 shows the main characteristics of activated sewage sludge, as well as the physical-chemical characteristics: moisture, ash, volatile matter and fixed carbon.

Table 1. Physical-chemical and chemical characteristics of sewage sludge, as described (Tchobanoglous et al., 2003; Fonts et al., 2009; Pokoma et al., 2009a; Samanya et al., 2012; Yuan et al., 2015; Castello et al., 2019; Zaharioiu et al., 2020)

\begin{tabular}{|c|c|}
\hline Parameter & Activated sludge \\
\hline Total dry solids (\%) & $0.8-1.2$ \\
\hline Volatile solids (\%) & $59.0-68.0$ \\
\hline Protein (\%) & $32.0-41.0$ \\
\hline Phosphorus (\%) & $0.5-0.7$ \\
\hline Grease and fats (\%) & $5.0-12.0$ \\
\hline Cellulose (\%) & $7.0-9.7$ \\
\hline C (\%) & 34.5 \\
\hline H (\%) & 5.0 \\
\hline N (\%) & 6.26 \\
\hline S (\%) & 0.86 \\
\hline O (\%) & 17.11 \\
\hline$C^{\text {fixed }}(\%)$ & 8.04 \\
\hline Calorific Value (kcal/kg) & 3456 \\
\hline
\end{tabular}

Table 2. Levels of heavy metals generally found in sewage sludge and their maximum permissible limits (Ningbo et al., 2020)

\begin{tabular}{|c|c|c|}
\hline Heavy metals & $\begin{array}{c}\text { Concentration } \\
(\mathbf{m g} / \mathbf{k g})\end{array}$ & $\begin{array}{c}\text { Limits* } \\
\text { (mg/kg) }\end{array}$ \\
\hline $\mathrm{As}$ & $5.6-56.1$ & No limit \\
\hline $\mathrm{Ba}$ & $41.5-1300$ & No limit \\
\hline $\mathrm{Cd}$ & 0.83 & $20-40$ \\
\hline $\mathrm{Cr}$ & 18.6 & No limit \\
\hline $\mathrm{Pb}$ & $4.0-429.8$ & $750-1200$ \\
\hline $\mathrm{Hg}$ & $0.1-1.1$ & $16-25$ \\
\hline $\mathrm{Mo}$ & $1.7-75$ & No limit \\
\hline $\mathrm{Ni}$ & $8.6-420$ & $300-400$ \\
\hline $\mathrm{Se}$ & 2 & No limit \\
\hline $\mathrm{Zn}$ & $0.0-7500$ & $2500-4000$ \\
\hline $\mathrm{Cu}$ & 75.8 & $1000-1750$ \\
\hline
\end{tabular}

Note: * maximum permissible limits in accordance with the $\mathrm{EU}$ regulations

The ash resulting from the sewage sludge contains minerals, such as quart, calcite and microline, which are formed from $\mathrm{Fe}, \mathrm{Ca}, \mathrm{K}$ and $\mathrm{Mg}$. The energy value of the sewage sludge depends on the type of sludge, increasing with the decrease of moisture and ash content. The energy value of the 
sewage sludge obtained from wastewater industries treatment plants is higher than the energy value of the sewage sludge obtained from the wastewater urban treatment plants (Parnaudeau and Dignac, 2007; Fonts et al., 2009b).

Sewage sludge may be contaminated with different levels of heavy metals, such as: $\mathrm{Cr}, \mathrm{Ni}, \mathrm{Cu}, \mathrm{Zn}$, $\mathrm{Pb}, \mathrm{Cd}$ and $\mathrm{Hg}$, as shown in Table 2, comparatively with the maximum permissible limits accepted by the European Union (Fonts et al., 2009a; Alvarez et al., 2015).

\section{PYROLYSIS PROCESS}

Before being subjected to the pyrolysis process, the sewage sludge must be dried, usually at temperatures of $100-105^{\circ} \mathrm{C}$ for 24 hours (Chen et al., 2018; Yongjie et al., 2018).

Pyrolysis is a process of decomposition of materials, producing vapors that can be condensed, biooil, and non-condensable vapors (syngas), as shown in Figure 1.

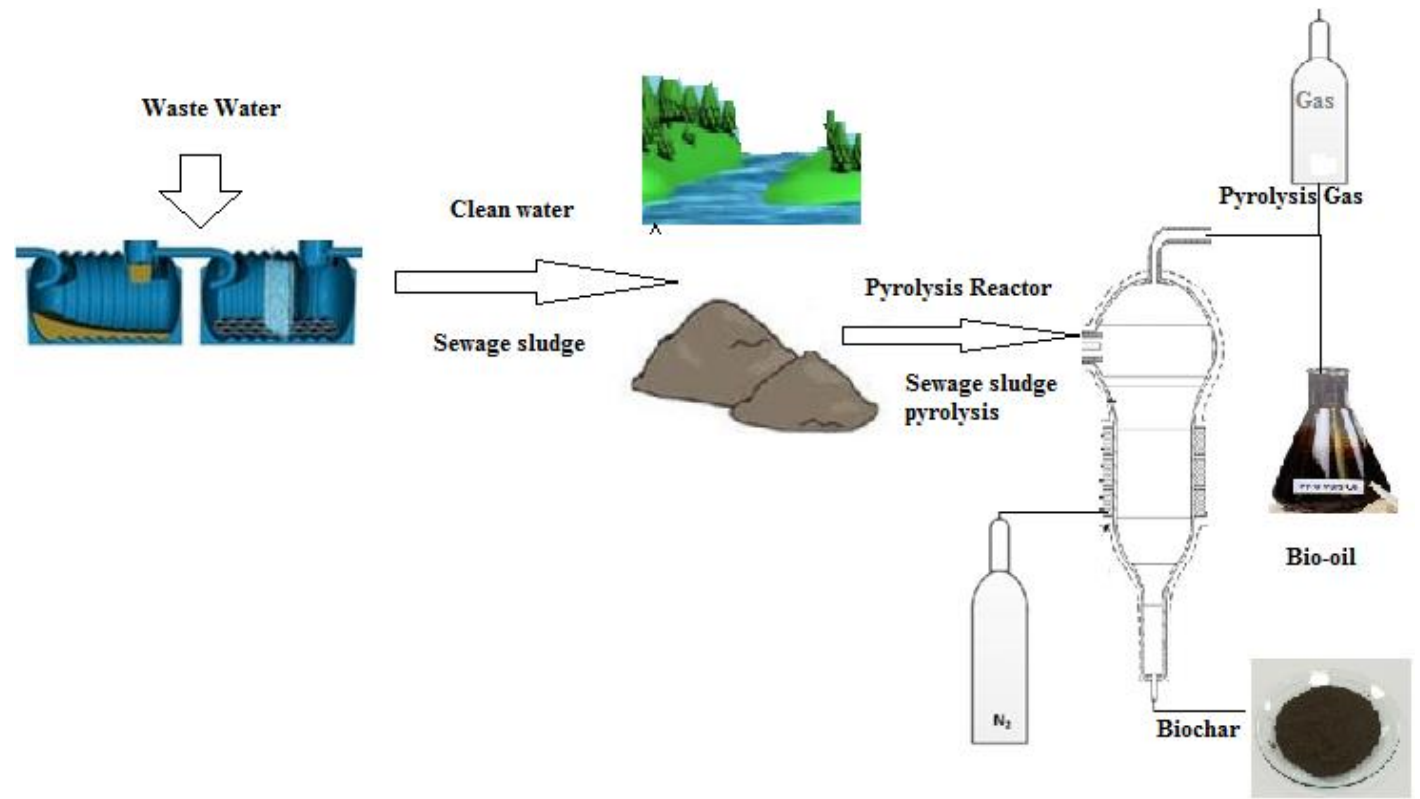

Figure 1. Scheme of the process of pyrolysis, from raw material to final products (Alvarez et al., 2015)

After the formation of pyrolysis products, a solid residue remains, called bio-char. The pyrolysis process is differentiated from the gasification process by the following aspects: gasification is performed under oxygen atmosphere in a proportion of $20 \%-40 \%$ obtaining combustible gas; pyrolysis takes place under inert nitrogen atmosphere, at higher temperatures of $500{ }^{\circ} \mathrm{C}-1000^{\circ} \mathrm{C}$, being a thermochemical reaction (Kim and Parker, 2008).

Pyrolysis is considered an environmentally friendly process because it reduces the emission of greenhouse gases, while heavy metals are concentrated in the final residue. The pyrolysis process applied to the sewage sludge can be of two types (Gopinath et al., 2021).

1. slow pyrolysis - performed at $300^{\circ} \mathrm{C}-800^{\circ} \mathrm{C}$, with a temperature increase rate of $1{ }^{\circ} \mathrm{C} / \mathrm{s}$;

2. rapid pyrolysis - performed at $500^{\circ} \mathrm{C}-1000^{\circ} \mathrm{C}$ with a temperature increase rate of $10{ }^{\circ} \mathrm{C}$ $-200{ }^{\circ} \mathrm{C} / \mathrm{s}$

The type and composition of the final products obtained from the pyrolysis process of the sewage sludge may differ depending on the temperature of the pyrolysis process. The average temperature 
is used to optimize the production of bio-oil (Yaman, 2004; Stuard et al., 2006; Briens et al., 2008; Fonts et al., 2009b; Ferreiro-Domingues et al., 2012; Karaca et al., 2018). In addition to the temperature parameter, others can be varied, such as: sludge particle size, resistance time, heating rate (Basu, 2010). During the pyrolysis process, two temperature ranges can be identified. The first interval is between $180{ }^{\circ} \mathrm{C}-550{ }^{\circ} \mathrm{C}$, where the pyrolysis of the reactive compounds takes place, for the most part, and less the pyrolysis of the less active compounds (Uban and Antal, 1982; Conesa et al., 1997; Conesa et al., 1998; Fonts et al., 2001; Magdziarz and Werle, 2014). During this temperature range, the loss of volatile matter, the rupture and the appearance of free radicals that lead to the formation of gases such as $\mathrm{CO}$ and $\mathrm{CO}_{2}$ and the bio-char residue, are achieved (Balat, 2008). The second temperature range, $385{ }^{\circ} \mathrm{C}-550{ }^{\circ} \mathrm{C}$, is conducted for the pyrolysis of less reactive compounds. The organic compounds remaining in the bio-char can then be transformed into tar and secondary bio-char (Kouloumbis et al., 2000; Shao et al., 2008; Kargbo, 2010; Siddiquee and Rohani, 2011; Yin, 2012; Gao et al., 2014; Nowicki and Ledakowicz, 2014).

\subsection{SYNGAS}

The pyrolysis process of the sewage sludge generates the syngas, which consists of hydrocarbons such as $\mathrm{CH}_{4}$, along with $\mathrm{CO}_{2}, \mathrm{CO}, \mathrm{H}_{2}, \mathrm{O}_{2}, \mathrm{~N}_{2}$ and water (Shen and Zhang, 2003).

At lower pyrolysis temperatures $\left(250-350{ }^{\circ} \mathrm{C}\right)$, the predominant gas is $\mathrm{CO}_{2}$, but also $\mathrm{N}_{2}$. Increasing the temperature of the pyrolysis process leads to an increase in $\mathrm{CO}$ and $\mathrm{H}_{2}$, and a decrease in $\mathrm{CO}_{2}$. Hydrocarbons $\left(\mathrm{CH}_{4}, \mathrm{C}_{2} \mathrm{H}_{4}, \mathrm{C}_{2} \mathrm{H}_{6}\right)$ form in a high yield, in particular $\mathrm{CH}_{4}$ at the pyrolysis process temperature of $600{ }^{\circ} \mathrm{C}$, and $\mathrm{C}_{2} \mathrm{H}_{4}$ and $\mathrm{C}_{2} \mathrm{H}_{6}$ at $450{ }^{\circ} \mathrm{C}$ (Inguanzo et al., 2002).

\subsection{BIO-OIL}

The bio-oil obtained following the pyrolysis process of the sewage sludge has a dark brown color (Ju et all., 2010). It consists of an aqueous phase, an inorganic phase and a mixture of organic compounds. The water must be removed from the bio-oil by filtration, the obtained liquid being reddish-brown (Onay, 2007; Briens et al., 2008; Meier et al., 2013). It contains hydrocarbons, such as alkanes, alkenes, alkynes, aromatic hydrocarbons. The amount of hydrocarbons increases with the reaction temperature, but also the water content increases with the reaction temperature, from $27 \%$ to $54 \%$ (Park et al., 2010).

Bio-oil can be used as an alternative fuel for fossil fuels. For this, bio-oil must undergo a process of fragmentation, recovery and refining (Park et al., 2010). The physical-chemical properties of biooils can vary depending on the applied technology, but also on the raw material being used. The main problem in the use of bio-oils in diesel engines is the amount of water in their component, but also the lower calorific value and high acidity. The physical-chemical properties of bio-oils are directly related to the behavior of the fuel used in the engine, the performance of the system and the engine (Pokoma et all., 2009). Sometimes there can be ignition complications if the fuel quality is low. For these reasons, bio-oil must be improved according to the standard of motor fuels (Yang et al., 2013).

\subsection{BIO-CHAR}

The process of pyrolysis of sewage sludge results in a final residue called bio-char. It is rich in carbon, but also in inorganic components (Bridgwater, 2012). Bio-char has high ash content (65.9\%) due to the high content of inorganic substances from the raw material, sewage sludge, remaining in the biochar following the pyrolysis process. The energy value of biochar is, as 
presented in the literature, $7.4 \mathrm{MJ} / \mathrm{kg}$ (Fonts et al., 2012; Lu et all., 2013). Due to the high ash content of biochar, its energy value is low.

Bio-char can be used as an adsorbent after undergoing a process of thermal and chemical activation (Gu et al., 2013). Adsorbent developed from bio-char can be used for the capture and storage $\mathrm{CO}_{2}$ and other gaseous pollutants, such as $\mathrm{H}_{2} \mathrm{~S}$ and $\mathrm{CO}_{2}$, after undergoing a process of thermal and chemical activation (Monsalvo et al., 2012; Gu et al., 2013). The preparation of biochar as an adsorbent has several stages: drying of the sewage sludge to remove the high water content, carbonization of the dehydrated sewage sludge and chemical and physical activation to obtain the biochar (Bonfiglioli et al., 2014).

\section{ECONOMICAL AND ENVINROMENTAL ADVANTAGES}

The pyrolysis process and its products have several economic and environmental advantages. The main advantage is the disposal of wastes, such as sewage sludge, in order to develop alternative and renewable fuels that contain high levels of environmentally friendly carbon. The raw material is available in large quantities and for free. This process develops autonomous energy with high economic potential, given the environmental potential.

The pyrolysis has the potential for different chemicals production, thus developing alternative, economic and environmental resources (Agrafioti et al., 2013). Even if the sewage sludge has in its composition heavy metals (chromium, lead, copper, nickel), some of them evaporate at high specific temperatures during the pyrolysis process (arsenic, cadmium, mercury), while others accumulate in bio-char, usually their levels being within the allowed limits (Lester at al., 1983; Ormrod and Webster, 2000; Angerbauer et al., 2008; Barbosa et al., 2009; Azuara et al., 2010; Jahirul et al., 2012).

\section{CONCLUSIONS}

Growing global population, chaotic energy consumption, declining fossil fuels, and increasing waste production have caused major concerns due to their long-term effects on the environment, causing greenhouse gas emissions, which are responsible of global warming.

Wastes such as sewage sludge represent an alternative for the production of sustainable and renewable fuel, as such wastes are generated in large volumes, for free, being less polluting as biofuel. The resulted biofuels from the pyrolysis of sewage sludge are efficient compared to fossil fuels. Among the different types of processes for energy production, pyrolysis, gasification, incineration, the pyrolysis process is the most appropriate because it takes place under nitrogen atmosphere and in the absence of oxygen, generating valuable final products, bio-oil, syngas and bio-char.

\section{REFERENCES}

Agrafioti, E., Bouras, G., Kalderis, D., Diamadopoulos, E. (2016). Biochar production by sewage sludge pyrolysis. Journal of Analytical and Applied Pyrolysis, 101, 72-78.

Alvarez, J., Amutio, M., Lopez, G., Barbarias, I., Bilbao, J., Olazar, M. (2015). Sewage sludge valorization by flash pyrolysis in a conical spouted bed reactor. Chemical Engineering Journal, 273, 173-183.

Angerbauer, C., Siebenhofer, M., Mittelbach, M., Guebitz, G.M. (2008). Conversion of sewage sludge into lipids by Lipomyces starkeyi for biodiesel production. Bioresource Technology, 99, 3051-3056.

Azuara, M., Abrego, J., Fonts, I., Gea, G. (2010). Ammonia content of bottom phase liquid from pyrolysis of sewage sludge in a bubbling fluidized bed. Proceedings of the 18th European Biomass Conference Exhibition.

Balat, M. (2008). Mechanisms of thermochemical biomass conversion processes. Part 1: reactions of pyrolysis. Energy Sources, 30, 620-635. 


\section{Current Trends in Natural Sciences}

Vol. 10, Issue 19, pp. 16-24, 2021

https://doi.org/10.47068/ctns.2021.v10i19.002

Current Trends in Natural Sciences (on-line)

ISSN: 2284-953X

Current Trends in Natural Sciences (CD-Rom)

ISSN: 2284-9521

ISSN-L: 2284-9521

ISSN-L: 2284-9521

Barbosa, R., lapa, N., Boavida, D., Lopes, H. (2009). Co-combustion of coal and sewage sludge: Chemical and ecotoxicological properties of ashes. Journal of Hazardous Materials, 170, 902-9.

Bonfiglioli, L., Bianchini, A., Pellegrini, M., Saccani, C. (2014). Sewage sludge: characteristics and recovery options. Materials Science.

Bridgwater, A.V. (2012). Review of fast pyrolysis of biomass and product upgrading. Biomass Bioenergy, $38,68-94$.

Briens, C., Piskorz, J., Berruti, F. (2008). Biomass valorization for Fuels and Chemicals Productions-A review. International Journal of Chemical Reactor Ingineering, 6.

Cantinho, P., Matos, M., Trancoso, M.A., Correira dos Santos, M.M. (2016). Behaviour and fate of metals in urban wastewater treatment plants: a review. International Journal of Environment Science Technology, 13, 359-386.

Capareda, S.C. (2013). Introduction to Biomass Energy Conversions. In B., Raton, eds, Introduction to Biomass Energy Conversions, New York, London.

Castello, D., Haider, M.S., Rosendahl, L.A. (2019). Catalytic upgrading of hydrothermal liquefaction biocrudes: Different challenges for different feedstocks. Renewable Energy, 141, 420-430.

Chen, Y., Wang, T., Zhou, M., Hou, H., Xue, Y., Wang, H. (2018). Rice husk and sewage sludge co-combustion ash: Leaching behavior analysis and cementitious property. Construction Building Materials, 163, 63-72.

Chiang, Y., Juang, R. (2017). Surface modifications of carbonaceous materials for carbon dioxide adsorption: a review. Journal of Taiwan Institute of Chemical Engineers, 71, 214-234.

Conesa, J., Marcilla, A., Prats, D., Rodriguez-Pastor, M. (1997). Kinetic study of the pyrolysis of sewage sludge. Waste Management Resources, 15, 293-305.

Conesa, J., Marcilla, A., Moral, L., Moreno-Caselles, J., Perez-Espinosa, A. (1998). Evolution of gases in the primary pyrolysis of different sewage sludges. Thermochim Acta, 313, 63-73.

Deng, S., Wei, H., Chen, T., Wang, B., Huang, J., Yu, G. (2014). Superior CO2 adsorption on pine nut shellderived activated carbons and the effective micropores at different temperatures. Chemical Engineearing Journal, 253, 46-54.

Dress, D. (2002). Recycling Routes for Sewage Sludge. European Commission. Office for Official Publications of the European Communities.

Ferreiro-Dominguez, N., Rigueiro-Rodriguez, A., Mosquera-Losada, M.R. (2012). Sewage sludge fertilizer use:Implications for soil and plant cooper evolution in forest and agronomic soils. Science of The Total Environment, 424, 39-47.

Font, R., Fullana, A., Conesa, J.A., Llavador, F. (2001). Analysis of the pyrolysis and combustion of different sewage sludges by TG. Journal of Analytical and Applied Pyrolysis, 58, 927-941.

Fonts, I., Azuara, M., Gea, G., Murillo, M.B. (2009a). Study of the pyrolysis liquids obtainedfrom different sewage sludge. Journal of Analytical and Applied Pyrolysis, 85, 184-91.

Fonts, I., Juan, A., Gea, G., Murillo, M.B., Arauzo, Z. (2009b). Sewage sludge pyrolysis in a fluidized bed, 2: influence of operating conditions on some physicochemical properties of the liquid product. Industrial and Engineering Chemistry Research, 48, 2179-87.

Fonts, I., Gea, G., Azuara, M., Abrego, J. (2012). Sewage sludge pyrolysis for liquid production: a review. Renewable and Sustainable Energy Reviews, 16, 2781-805.

Fytili, D., Zabaniotou, A. (2008). Utilization of sewage sludge in EU application of old and new methods-a review. Renewable and Sustainable Energy Reviews, 12, 116-40.

Gao, N.B., Li, J.J., Qi, B.Y., Li, A.M., Duan, Y., Wang, Z. (2014). Thermal analysis and products distribution of dried sewage sludge pyrolysis. Journal of Analytical and Applied Pyrolysis, 105, 43-8.

Gao, N., Kamran, k., Quana, C., Williams, P.T. (2020). Thermochemical conversion of sewage sludge: A critical review. Progress in Energy and Combustion Science, 79, 100843.

Gopinath, A., Divyapriya, G., Srivastava, V., Laiju, A.R., Nidheesh, P.V., Suresh Kumar, M. (2021). Conversion of sewage sludge into biochar: A potential resources in water and wastewater treatment. Environmental Research, 194, 110656.

Gu, L., Wang, Y.C., Zhu, N.W., Zhang, D.F., Huang, S.Q., Yuan, H.P. (2013). Preparation of sewage sludge based activated carbon by using Fenton's reagent and their use in 2-Naphthol adsorption. Bioresources Technology, 146, 779-84.

Hong, S.M., Choi, S.W., Kim, S.H., Lee, K.B. (2016). Porous carbon based on polyvinylidene fluoride: enhancement of $\mathrm{CO} 2$ adsorption by physical activation. Carbon, 99, 354-60.

Hong, S.M., Jang, E., Dysart, A.D., Pol, V.G., Lee, K.B. (2016). CO2 capture in the sustainable wheat-derived activated microporous carbon compartments. Scientific Reports, 6, 1-10. 


\section{Current Trends in Natural Sciences}

Vol. 10, Issue 19, pp. 16-24, 2021

https://doi.org/10.47068/ctns.2021.v10i19.002

Current Trends in Natural Sciences (on-line)

ISSN: 2284-953X

Current Trends in Natural Sciences (CD-Rom)

ISSN: 2284-9521

ISSN-L: 2284-9521

ISSN-L: 2284-9521

Hwang, I., Ouchi, Y., Matsuto, T. (2007). Characteristics of leachate from pyrolysis residue of sewage sludge. Chemosphere, 68, 1913-9.

Inguanzo, M., Domınguez, A., Menendez, J.A., Blanco, C.G., Pis, J.J. (2002). On the pyrolysis of sewage sludge: the influence of pyrolysis conditions on solid, liquid and gas fractions. Journal of Analytical and Applied Pyrolysis, 63, 209-22.

Jacobson, M.Z. (2009). Review of solutions to global warming, air pollution, and energy security. Energy Environment Science, 2, 148-73.

Jahirul, M.I., Rasul, M.G., Chowdhury, A.A., Ashwath, N. (2012). Biofuels production through biomass pyrolysis - a technological review. Energies, 5, 4952-5001.

Jang, E., Choi, S.W., Hong, S.M., Shin, S., Lee, K.B. (2018). Development of a cost-effective $\mathrm{CO}_{2}$ adsorbent from petroleum coke via KOH activation. Applied Surface Science, 429, 62-71.

Ju, H., Park, Heo, S.H., Park, Y.K., Yim, J.H., Jeon, J.K., Park, J., Ryu, C., Kim, S.S. (2010). Clean bio-oil production from fast pyrolysis of sewage sludge: Effects of reaction conditions and metal oxide catalysts. Bioresource Technology, 101, S83-S85.

Kan, T., Strezov, V., Evans, T. (2016). Effect of the heating rate on the thermochemical behavior and biofuel properties of sewage sludge pyrolysis, Energy Fuels, 30, 1564-1570.

Karaca, C., Sozen, S., Orhon, D., Okutan, H. (2018). High temperature pyrolysis of sewage sludge as a sustainable process for energy recovery. Waste Management, 78, 217-226.

Kargbo, D.M. (2010). Biodiesel production from municipal sewage sludges. Energy Fuels, 24, 2791-4.

Khiari, B., Marias, F., Zagrouba, F., Vaxelaire, J. (2004). Analytical study of the pyrolysis process in a wastewater treatment pilot station. Desalination, 167, 39-47.

Kim, Y., Parker, W. (2008). A technical and economic evaluation of the pyrolysis of sewage sludge for the production of bio-oil. Bioresources Technology, 99, 1409-16.

Kouloumbis, P., Rigas, F., Mavridou, A. (2000). Environmental problems from the disposal of sewage sludge in Greece. International Journal of Environment Health Research, 10, 77-83.

Lee, S.Y., Park, S.J. (2015). A review on solid adsorbents for carbon dioxide capture. Journal of Industrial Engineering Chemistry, 23, 1-11.

Leng, L.J., Yuan, X.Z., Shao, J.G., Huang, H.J., Wang, H., Li, H., Chen, X.H., Zeng, G.M. (2016). Study on demetalization of sewage sludge by sequential extraction before liquefaction for the production of cleaner bio-oil and bio-char. Bioresource Technology, 200, 320-327.

Lester, J., Sterritt, R., Kirk, P. (1983). Significance and behaviour of heavy metals in waste water treatment processes II. Sludge treatment and disposal. Science of the total environment, 30, 45-83.

Liu, W-J., Zeng, F-X., Jiang, H., Yu, H-Q. (2011). Total recovery of nitrogen and phosphorus from three wetland plants by fast pyrolysis technology. Bioresource Technology, 102, 3471-3479.

Liu, Y., Wilcox, J. (2011). CO2 adsorption on carbon models of organic constituents of gas shale and coal. Environment Science Technology, 45, 809-14.

Liu, H., Yi, L.L., Hu, H.Y., Xu, K., Zhang, Q., Lu, G., Yao, H. (2017). Emission control of NOx precursors during sewage sludge pyrolysis using an integrated pretreatment of Fenton peroxidation and $\mathrm{CaO}$ conditioning. Fuel, 195, 208-216.

Lu, H., Wang, S.Z., Zhang, W., Zhuang, L. (2013). Characterization of sewage sludge-derived biochars from different feedstocks and pyrolysis temperatures. Journal of Analytical and Applied Pyrolysis, 102, 137-43.

Magdziarz, A., Werle, S. (2014). Analysis of the combustion and pyrolysis of dried sewage sludge by TGA and MS. Waste Management, 34, 174-9.

Maguyon, M.C.C., Capareda, S.C. (2013). Evaluating the effects of temperature on pressurized pyrolysis of Nannochloropsis oculata based on products yields and characteristics. Energy Conversion Management, 76, 76473.

Manara, P., Zabaniotou, A. (2012). Towards sewage sludge based biofuels via thermochemical conversion e a review. Renewable Sustainable Energy Reviews, 16, 2566-82.

Meier, D., Van de Beld, B., Bridgwater, T., Elliott, D.C. (2013). State-of-the-art of fast pyrolysis in IEA bioenergy member countries. Renewable Sustainable Energy Reviews, 20, 619-41.

Milieu, Ltd., R., WRc (2010). Environmental, economic and social impacts of the use of sewage sludge on land Final Report Part I: Overview Report.

Monsalvo, V.M., Mohedano, A.F., Rodriguez, J.J. (2012). Adsorption of 4-chlorophenol by inexpensive sewage sludge-based adsorbents. Chemical Engineering Research and Design, 90, 1807-14. 


\section{Current Trends in Natural Sciences}

Vol. 10, Issue 19, pp. 16-24, 2021

https://doi.org/10.47068/ctns.2021.v10i19.002

Current Trends in Natural Sciences (on-line)

ISSN: 2284-953X

Current Trends in Natural Sciences (CD-Rom)

ISSN: 2284-9521

ISSN-L: 2284-9521

ISSN-L: 2284-9521

Nowicki, L., Ledakowicz, S. (2014). Comprehensive characterization of thermal decomposition of sewage sludge by TG-MS. Journal of Analytical and Applied Pyrolysis, 110, 220-8.

Onay, O. (2007). Influence of pyrolysis temperature and heating rate on the production of bio-oil and char from safflower seed by pyrolysis, using a well-swept fixed-bed reactor. Fuel Process Technogyl, 88, 523-31.

Ormrod, D., Webster, A. (2000). Progress in utilization of bio-oil in diesel engines. PyNe Newsletter, 10, 86-91.

Parnaudeau, V., Dignac, M.F. (2007). The organic matter composition of variouswastewater sludges and their neutral detergent fractions as revealed bypyrolysis-GC/MS. Journal of Analytical and Applied Pyrolysis, $78,140-52$.

Pathak, A., Dastidar, M., Sreekrishnan, T. (2009). Bioleaching of heavy metals from sewage sludge: a review. Journal of Environment Management, 90, 2343-53.

Peng, C., Zhai, Y.B., Zhu, Y., Xu, B.B., Wang, T.F., Li, C.T., Zeng, G.M. (20016). Production of char from sewage sludge employing hydrothermal carbonization: char properties, combustion behavior and thermal characteristics. Fuel, 176, 110-118.

Pokorna, E., Postelmans, N., Jenicek, P., Schreurs, S., Carleer, R., Yperman, J. (2009). Study of biooils and solids from flash pyrolysis of sewage sludges. Fuel, 88, 1344-50.

Rashidi, N.A., Yusup, S. (2016). An overview of activated carbons utilization for the post-combustion carbon dioxide capture. Journal of $\mathrm{CO} 2$ Utilisation, 13, 1-16.

Samanya, J., Hornung, A., Apfelbacher, A., Vale, P. (2012). Characteristics of the upper phase of bio-oil obtained from copyrolysis of sewage sludge with wood, rapeseed and straw. Journal of Analytical and Applied Pyrolysis, 94, $120-5$.

Shao, J., Yan, R., Chen, H., Wang, B., Lee, D.H., Liang, D.T. (2008). Pyrolysis characteristics and kinetics of sewage sludge by thermogravimetry Fourier transform infrared analysis. Energy Fuels, 22, 38-45.

Shen, L., Zhang, D.-K. (2003). An experimental study of oil recovery from sewage sludge by low-temperature pyrolysis in a fluidised-bed. Fuel, 82, 465-72.

Siddiquee, M.N., Rohani, S. (2011). Lipid extraction and biodiesel production from municipal sewage sludges: a review. Renewable Sustainable Energy Reviews, 15, 1067-72.

Singh, R., Agrawal, M. (2008). Potential benefits and risks of land application of sewage sludge. Waste Management, $28,347-58$.

Tchobanoglous, G., Burton, F.L., Stensel, H.D. (2003). Wastewater engineering: treatment and reuse. Environmental Research Information, 45268, 27.

Tian, Y., Zuo, W., Ren, Z.Y., Chen, D.D. (2011). Estimation of a novel method to produce biooil from sewage sludge by microwave pyrolysis with the consideration of efficiency and safety. Bioresource Technology, 102, 2053-61.

Tezel, U., Tandukar, M., Pavlostathis, S. (2011). Anaerobic biotreatment of municipal sewage sludge.Comprehensive Biotchnology, 6, 447-461, Atlanta.

Urban, D.L., Antal, Jr. M.J. (1982). Study of the kinetics of sewage sludge pyrolysis using DSC and TGA. Fuel, 61, 799-806.

Yaman, S. (2004). Pyrolysis of Biomass to produce Fuels and Chemical Feedstocks. Cheminform, 35, 651-671.

Yang, Y., Ouadi, M., Brammer, J.G., Samanya, J. (2013). Characterisation of waste derived intermediate pyrolysis oils for use as diesel engine fuels. Fuel, 103, 247-57.

Yin, C.G. (2012). Microwave-assisted pyrolysis of biomass for liquid biofuels production. Bioresource Technology, $120,273-84$.

Yuan, H., Lu, T., Huang, H., Zhao, D., Kobayashi, N., Chen, Y. (2015). Influence of pyrolysis temperature on physical and chemical properties of biochar made from sewage sludge. Journal of Analytical and Applied Pyrolysis, 112, 284-9.

Yu, Y., Wei, H., Yu, L., Gu, B., Li, X., Rong, X., Zhao, Y., Chen, L., Sun, C. (2016). Catalytic wet air oxidation of mcresol over a surface-modified sewage sludge-derived carbonaceous catalyst, Catalysis Science Technology, 6, $1085-1093$.

Zaharioiu, A., Bucura, F., Ionete, E.I., Ionete, R.E., Ebrasu, D., Sandru, C., Marin, F., Oancea, S., Niculescu, V., Miricioiu, M.G., Constantinescu, M. (2020). Thermochemical Decomposition of Sewage Sludge - An EcoFriendly Solution for a Sustainable Energy Future by Using Wastes. Revista Chimie, 71, 171-181.

Zhang, J., Zuo, W., Tian, Y., Yin, L., Gong, Z., Zhang, J. (2017). Release of hydrogen sulfide during microwave pyrolysis of sewage sludge: effect of operating parameters and mechanism, Journal of Hazardous Materials, $331,117-122$. 